Research/Technical Note

\title{
Metallic Oxides Nanoparticles: The New Frontier in EOR
}

\section{Odo Jude Emeka*, Anthony Chikwe, Ifeanyi Onyejekwe, Ifeanyi Oguamah, Nnanna Okoli, Ofoegbu Chukwuebuka Daniel}

Department of Petroleum Engineering, Federal University of Technology, Owerri, Nigeria

\author{
Email address: \\ jude.odo@futo.edu.ng (O. J. Emeka) \\ ${ }^{*}$ Corresponding author
}

\section{To cite this article:}

Odo Jude Emeka, Anthony Chikwe, Ifeanyi Onyejekwe, Ifeanyi Oguamah, Nnanna Okoli, Ofoegbu Chukwuebuka Daniel. Metallic Oxides Nanoparticles: The New Frontier in EOR. American Journal of Applied Scientific Research. Vol. 6, No. 3, 2020, pp. 61-66.

doi: 10.11648/j.ajasr.20200603.11

Received: January 28, 2020; Accepted: April 22, 2020; Published: July 17, 2020

\begin{abstract}
With the rate at which most fields are becoming marginal and money is sunk to effectively recover more oil, there still lie factors that hinder oil recovery. Some of these factors are cost of recovery material, shear resistance of materials, stability of recovery materials in subsurface conditions, environmental friendliness of recovery material, ease of handling material etc. Nanoparticle EOR is a relatively new EOR technique with little or no application in the oil and gas industry. Though it is mostly still under experimentation in various labs across the world. It has proved beyond any reasonable doubt to fulfill the above stated loopholes in EOR. It also reduces interfacial tension, capillary pressure, wettability of oil, etc. with high displacement efficiency at low cost. This journal work is based on the recovery efficiency of three metallic oxides nanoparticles and their different characteristics which are very important to oil recovery. From the experimental work, it was found that aluminum oxide nanoparticles reduced interfacial tension and viscosity with a very high recovery factor, silicon oxide nanoparticles rapidly reduced wettability with a high recovery as well as magnesium oxide nanoparticle with the least. However, each of the metallic oxide particle experimented and analyzed in a core flooding system have their very peculiar property uniquely suitable for EOR at low cost and high recovery. However, the concentration of nanoparticle plays a key role in its recovery ability. The higher the concentration, the more tendencies to agglomerate and hinder permeability, the lesser the concentration, the less effective it can be. In my research, different concentrations were considered to determine the optimum concentration of metallic oxide nanoparticles with little or no adverse effect to the formation rock and fluid properties with optimum recovery.
\end{abstract}

Keywords: Nanoparticles Application, EOR, Laboratory Core Flooding

\section{Introduction}

The lifeblood of most industrialized nations is oil. Since the 19th century, oil has become the world's most important source of energy with its product supporting modern societies mostly by supplying energy to power industries, war machineries, heat up homes, provide fuel for vehicles and airplanes to carry goods and people all over the world. Infact, oil meets over $95 \%$ of the transport sector of most nations in the world and it is also a raw material for the production of many everyday essentials.

But it is quite unfortunate that only about $25-30 \%$ of oil and gas are produced from their reservoirs at their natural pressure, therefore the need for secondary and tertiary recovery.
Secondary recovery has for long given us about 30-45\% recovery factor which is still relatively low, therefore the need for tertiary (enhanced oil recovery EOR). EOR has been giving a recovery factor of about $45-80 \%$ which is quite appreciable compared to other recovery methods. On the average the oil recovery from primary and secondary methods only accounts for about one-third of the OOIP, while the remaining two-third can be partly recovered through EOR [14]. EOR is achieved by altering the rock and fluid properties thereby recovering the residual oil that is trapped in the flooded area by capillary forces. Examples of EOR are thermal flooding, miscible flooding, chemical flooding etc. In chemical flooding, chemicals such as polymers, alkaline, surfactants and recently nano sized chemicals of aluminum oxides, silicon oxides, magnesium 
oxides, zinc oxides etc. are used [5].

The petroleum industry is faced with a number of challenges when considering the reservoir. Some of this challenges are wettability, formation damage, low sweep efficiency, cost if EOR etc. [10]. Though EOR is effective there are key challenges associated with it. For example, thermal EOR process is environmentally unfriendly due to emissions from surface steam generation systems, high operational cost, cement failure etc. In chemical EOR, pore plugging, high cost etc. occurs. In gas EOR, inadequate sources of gas due to geographical unavailability, adverse mobility problems occur [11].

Nanofluids (a solution of nanoparticles) are used in EOR to alter the properties of oil thereby helping in the recovery of residual oil in place. These nanoparticles are of the size of $1-100 \mathrm{~nm}$ and have the capacity to reduced oil viscosity, interfacial tension IFT thus enabling the migration of oil from the reservoir to the production wellbore.

Nanoparticle utilization in EOR has received great interest and concern with controversial results, though proven to be highly effective in improving oil recovery [1]. Furthermore, EOR by nanoparticles is environmentally friendly, cheap and easy to apply in oil fields [5].

In addition, new nanomaterials have been proven to give high strength, high stability under high temperature and pressure reservoir conditions and are less susceptible to corrosion [8]. Though when surfactants are added to high molecular weight polymers, viscosity increases and complexes which are less susceptible to shear degradation are formed. However, the excessive increase in the surfactants concentration disrupts the association with a resultant decrease in viscosity of the displacing fluid [6]. Aluminum oxide nanoparticles reduced interfacial tension and viscosity with a very high recovery factor, silicon oxide nanoparticles rapidly reduced wettability [12]. They exhibit great stability over a wide range of temperature and favorable rheological and flow behavior [3], while at higher temperatures, the chemical bonds of polymers and surfactants are weak and easily break down irreversibly [13]. Metallic oxides nanoparticles have been proved to be a favorable material that can be easily transported through limestone and dolomite porous media [2]. The mobility of nanoparticles in porous medium greatly increases with temperature which reduces the adsorption of these particles in their preliminary stage after injection [15]. Nanoparticles especially multi-metallic nanoparticles can be transported through oil sands porous media into heavy oil reservoirs in other to serve as catalyst for upgrading [7].

Generally, in the oil and gas industry, nanoparticles are applied in the following aspects namely: Chemical flooding, water and gas coning control, flow assurance, Stimulation of low permeability oil and gas reservoirs, etc. It is also very pertinent in the reduction of viscosity which is a very important factor in EOR [8].

Finally, there are some cons in the use of nanoparticles EOR and one of them is permeability alteration/reduction by about $41-72 \%$ [9]. When a nanoparticle is dissolved in an acidic solvent, it tends to increase in its morphology and when it is dissolved in a basic solvent, it tends to decrease in its morphology [4]. As a result, there is need to conduct experimental studies on permeability alterations due to nanoparticles retention in porous media in nanotechnology assisted enhanced oil recovery so as to know the kind, concentration and environment a particular nanoparticle will function effectively with little or no serious alteration to formation permeability.

\section{Materials and Methods}

\subsection{Apparatus/Equipment}

Flat bottom flask, measuring cylinder, retort stand, AFS core flooding system, aluminum foil, mesh, masking tape, cutting machine, meter rule, veiner caliper, face mask, oven, weighing balance, sieve shaker, plastic bowl, viscometer, densitometer, magnetic stirrer, PPE and saturator.

\subsection{Materials}

Distilled water, industrial salt, aluminum oxide, silicon oxide, magnesium oxide nanoparticles, crude oil, 63-250 microns grain size distribution.

\subsection{Sand Pack Preparation}

Preparation of sand packs or unconsolidated core plugs were done by cutting aluminum foils each of $7 \mathrm{~cm}$ length and soaking in water to remove entrained carton.

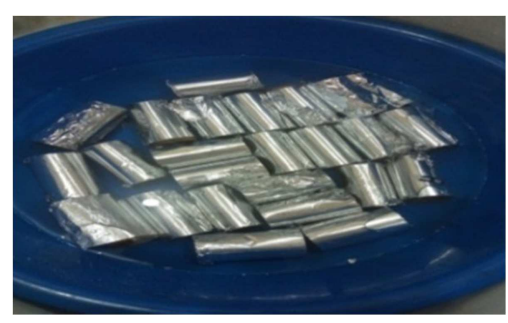

Figure 1. Aluminum foil.

Core plug is formed by consolidation the hollow aluminum foil with sand about $63-250$ micron in grain size distribution. Then the ends of the cylindrical packs are covered with mesh and then the sand pack is saturated with brine (@30g/liter)by a saturator.

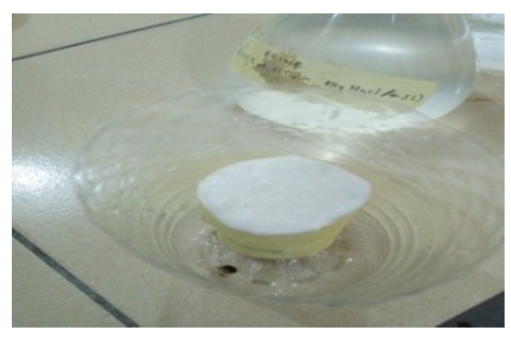

Figure 2. Prepared sand pack.

In general, 12 sand packs were prepared, 3 controls, 3 silicon oxide, 3 aluminum and 3 magnesium oxide 
nanoparticles. 2 were used and 1 was kept each to mitigate unforeseen occurrences.

\subsection{Nanofluid Preparation}

The nanofluid was prepared by dissolving $0.1 \mathrm{wt} \%$ and 0.2 $\mathrm{wt} \%$ of individual nanopowders in a brine solution of $30 \mathrm{~g} /$ liters. A magnetic stirrer was used to uniformly disperse the solute in the solution so as to prevent plugging of core flooding tubes as well as to ensure uniform concentration.

Table 1. Different nanoparticle concentrations and the alphabet attached to them during the core flooding system.

\begin{tabular}{lll}
\hline Composition & Alphabet & Concentration \\
\hline \multirow{2}{*}{ Control } & C1 & Nil \\
& C2 & Nil \\
Silicon oxide & D1 & $0.2 \% \mathrm{wt}$ \\
& D2 & $0.4 \% \mathrm{wt}$ \\
Aluminum oxide & E1 & $0.2 \% \mathrm{wt}$ \\
& E2 & $0.4 \% \mathrm{wt}$ \\
Magnesium oxide & F1 & $0.2 \% \mathrm{wt}$ \\
& F2 & $0.4 \% \mathrm{wt}$ \\
\hline
\end{tabular}

\subsection{Core Flooding}

Core plug was fixed into the core barrel and the core barrel was put in place in the core holder. The core holder was fixed into the AFS core flooding system and necessary connections were made. Brine was filled into the accumulator $\mathrm{A}$ in the core flooding system up to $1000 \mathrm{ml}$ or less. Oil was filled into the accumulator B in the core flooding system up to $1000 \mathrm{ml}$ or less. The existing differential pressure in the core flooding system was confirmed and the differential pressure in the core flooding system was zero trimmed. Then the flow rate of 1 $\mathrm{mil} / \mathrm{min}$ was set for water to fill the lines prior to heating. The oven was heated up to $45^{\circ} \mathrm{C}\left(113^{\circ} \mathrm{F}\right)$ and pressure of about $3000-3500$ psi was applied radially to the sand pack in the core holder. Injection of oil into the brine saturated sand pack (drainage) thereby resulting in the determination of OOIP by the Archimedes' principle. Imbibition or water flooding by brine to determine the initial oil saturation after secondary recovery. EOR by nanopowders was done by replacing brine with nanofluid in accumulator $\mathrm{A}$ at different concentrations.

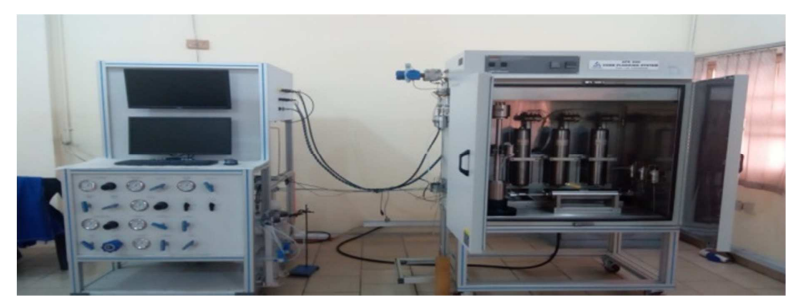

Figure 3. AFS core flooding system.

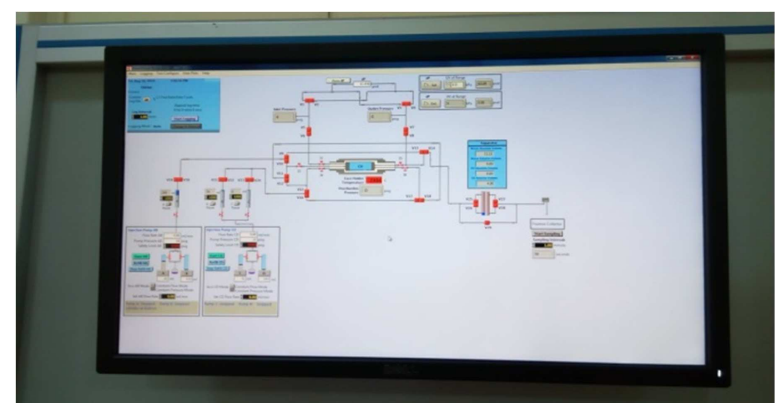

Figure 4. PFD of the AFS core flooding system.

\section{Result}

The following results were obtained at the end of the experiment.

Table 2. Result of Nanoparticle Permeability Alteration and EOR.

\begin{tabular}{|c|c|c|c|c|c|c|}
\hline $\mathbf{s} / \mathbf{n}$ & Conc & Agent & Sample name & Abs. Perm (mD) & $\begin{array}{l}\text { Eff. Perm during EOR-assisted } \\
\text { waterflooding }(\mathrm{mD})\end{array}$ & $\begin{array}{l}\text { Displacement } \\
\text { Efficiency (\%) }\end{array}$ \\
\hline \multirow[t]{2}{*}{1} & N/A & Control & $\mathrm{C}$ & 1269 & N/A & 73.33 \\
\hline & & Silicon oxide & $\mathrm{D}$ & 1211 & 356 & 80.00 \\
\hline \multirow[t]{3}{*}{2} & $0.2 \mathrm{wt} \%$ & Aluminum oxide & $\mathrm{E}$ & 1214 & 729 & 93.75 \\
\hline & & Magnesium oxide & $\mathrm{F}$ & 911 & 250 & 76.92 \\
\hline & & Silicon oxide & $\mathrm{D}$ & 729 & 405 & 91.67 \\
\hline \multirow[t]{2}{*}{3} & $0.4 \mathrm{wt} \%$ & Aluminum oxide & $\mathrm{E}$ & 1197 & 399 & 97.50 \\
\hline & & Magnesium oxide & $\mathrm{F}$ & 729 & 258 & 83.33 \\
\hline
\end{tabular}

Table 3. Fluid Properties at Ambient Conditions.

\begin{tabular}{|c|c|c|c|c|c|c|c|c|}
\hline Properties & $\begin{array}{l}\text { Brine (30g } \\
\mathrm{NaCl})\end{array}$ & $\begin{array}{l}\text { Brine (with } \\
0.2 \% \mathrm{Al}_{2} \mathrm{O}_{3} \text { ) }\end{array}$ & $\begin{array}{l}\text { Brine (with } \\
0.4 \% \mathrm{Al}_{2} \mathrm{O}_{3} \text { ) }\end{array}$ & $\begin{array}{l}\text { Brine (with } \\
0.2 \% \mathrm{MgO} \text { ) }\end{array}$ & $\begin{array}{l}\text { Brine (with } \\
0.4 \% \mathrm{MgO} \text { ) }\end{array}$ & $\begin{array}{l}\text { Brine (with } \\
0.2 \% \mathrm{SiO}_{2} \text { ) }\end{array}$ & $\begin{array}{l}\text { Brine (with } \\
0.4 \% \mathrm{SiO}_{2} \text { ) }\end{array}$ & Crude Oil \\
\hline Density $\left(\mathrm{g} / \mathrm{cm}^{3}\right)$ & 1.0167 & 1.0171 & 1.0191 & 1.0146 & 0.9996 & 1.0189 & 1.0183 & 0.9110 \\
\hline S. G & 1.0202 & 1.0203 & 1.0224 & 1.0178 & 1.0028 & 1.0221 & 1.0215 & 0.9138 \\
\hline${ }^{\circ} \mathrm{API} @ 15^{\circ} \mathrm{C}$ & - & - & - & - & - & - & - & 22.46 \\
\hline Dynamic Viscosity (cP) & 0.95 & 0.97 & 0.86 & 0.96 & 0.91 & 1.04 & 0.94 & 60.2 \\
\hline
\end{tabular}

Table 4. Fluid properties at $45^{\circ} \mathrm{C}\left(113^{\circ} \mathrm{F}\right)$.

\begin{tabular}{|c|c|c|c|c|c|c|c|c|}
\hline Properties & $\begin{array}{l}\text { Brine } \\
(30 \mathrm{~g} / \mathrm{l} \mathrm{NaCl})\end{array}$ & $\begin{array}{l}\text { Brine (with } \\
0.2 \% \mathrm{Al}_{2} \mathrm{O}_{3} \text { ) }\end{array}$ & $\begin{array}{l}\text { Brine (with } \\
0.4 \% \mathrm{Al}_{2} \mathrm{O}_{3} \text { ) }\end{array}$ & $\begin{array}{l}\text { Brine (with } \\
0.2 \% \mathrm{MgO} \text { ) }\end{array}$ & $\begin{array}{l}\text { Brine (with } \\
0.4 \% \mathrm{MgO} \text { ) }\end{array}$ & $\begin{array}{l}\text { Brine (with } \\
0.2 \% \mathrm{SiO}_{2} \text { ) }\end{array}$ & $\begin{array}{l}\text { Brine (with } \\
0.4 \% \mathrm{SiO}_{2} \text { ) }\end{array}$ & Crude Oil \\
\hline Density $\left(\mathrm{g} / \mathrm{cm}^{3}\right)$ & 1.0063 & 1.0111 & 1.0131 & 1.0066 & 0.9678 & 1.0129 & 1.0123 & 0.8991 \\
\hline S. G@15² & 1.0142 & 1.0203 & 1.0204 & 1.0138 & 0.9749 & 1.0221 & 1.0204 & 0.9078 \\
\hline Dynamic Viscosity in $\mathrm{cp}$ & 0.66 & 0.66 & 0.66 & 0.68 & 0.61 & 0.68 & 0.66 & 19.2 \\
\hline
\end{tabular}


Table 5. Rock Properties.

\begin{tabular}{|c|c|c|c|c|c|c|c|c|c|c|c|}
\hline Composition & $\begin{array}{l}\text { Sample } \\
\text { ID }\end{array}$ & $\begin{array}{l}\text { Dry Weight } \\
\text { (g) }\end{array}$ & $\begin{array}{l}\text { Wet } \\
\text { Weight (g) }\end{array}$ & $\begin{array}{l}\text { Length } \\
\text { (cm) }\end{array}$ & $\begin{array}{l}\text { Diameter } \\
\text { (cm) }\end{array}$ & $\begin{array}{l}\text { Cross Sectional } \\
\text { Area }\left(\mathrm{cm}^{2}\right)\end{array}$ & $\begin{array}{l}\text { Pore Volume } \\
\left(\mathrm{cm}^{3}\right)\end{array}$ & $\begin{array}{l}\text { Bulk Volume } \\
\left(\mathrm{cm}^{3}\right)\end{array}$ & $\begin{array}{l}\text { Porosit } \\
\text { y (\%) }\end{array}$ & $\begin{array}{l}\text { OOIP } \\
(\mathrm{ml})\end{array}$ & $\begin{array}{l}\text { Oil Recovered } \\
\text { (ml) }\end{array}$ \\
\hline \multirow{2}{*}{ CONTROL } & $\mathrm{C} 1$ & 128.8 & 156.0 & 7.0 & 3.8 & 11.346 & 26.75 & 79.42 & 33.68 & 15.0 & 11.0 \\
\hline & $\mathrm{C} 2$ & 127.3 & 153.2 & 7.0 & 3.9 & 11.951 & 25.48 & 83.66 & 30.46 & 13.0 & 9.0 \\
\hline SILICON & D1 & 134.4 & 161.1 & 7.5 & 3.5 & 9.625 & 26.26 & 72.19 & 36.38 & 12.5 & 10.0 \\
\hline OXIDE & D2 & 120.2 & 147.4 & 7.0 & 3.9 & 11.951 & 26.75 & 83.66 & 31.98 & 12.0 & 11.0 \\
\hline ALUMINIUM & E1 & 127.0 & 154.2 & 7.0 & 3.9 & 11.951 & 26.75 & 83.66 & 31.98 & 12.8 & 12.0 \\
\hline OXIDE & E2 & 126.8 & 154.0 & 6.9 & 3.9 & 11.951 & 26.75 & 82.46 & 32.44 & 12.0 & 11.7 \\
\hline MAGNESIUM & F1 & 125.7 & 151.2 & 7.0 & 3.9 & 11.951 & 25.08 & 83.66 & 29.98 & 13.0 & 10.0 \\
\hline OXIDE & F2 & 128.5 & 154.2 & 7.0 & 3.9 & 11.951 & 25.28 & 83.66 & 30.22 & 12.0 & 10.0 \\
\hline
\end{tabular}

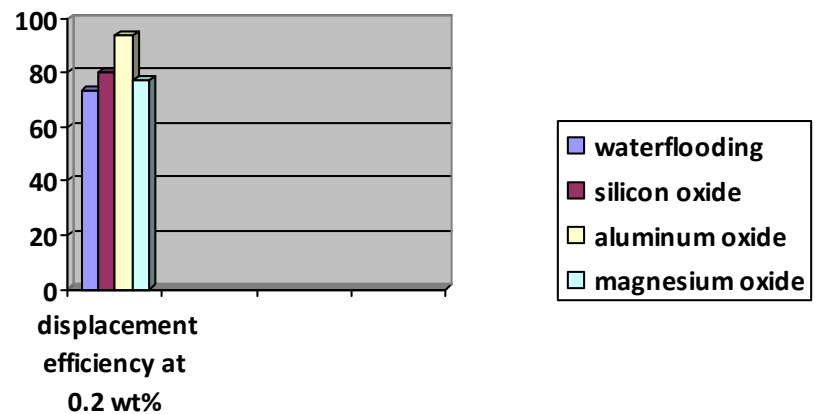

Figure 5. Displacement efficiency at a nanoparticle concentration of $0.2 \%$.

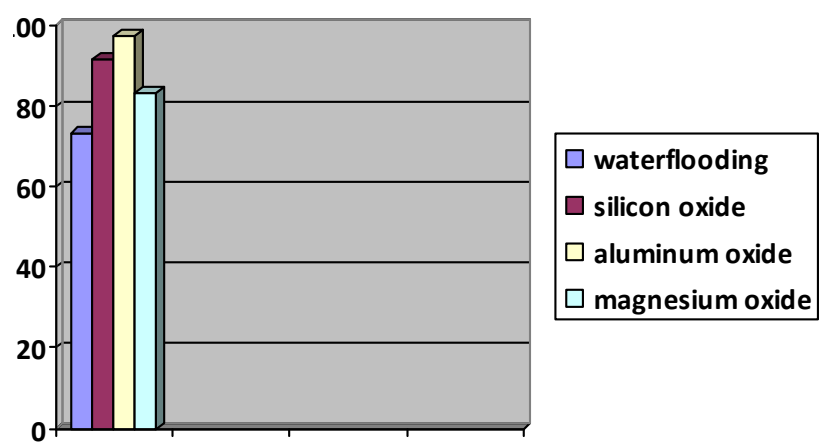

Figure 6. Displacement efficiency at a nanoparticle concentration of $0.4 \%$.

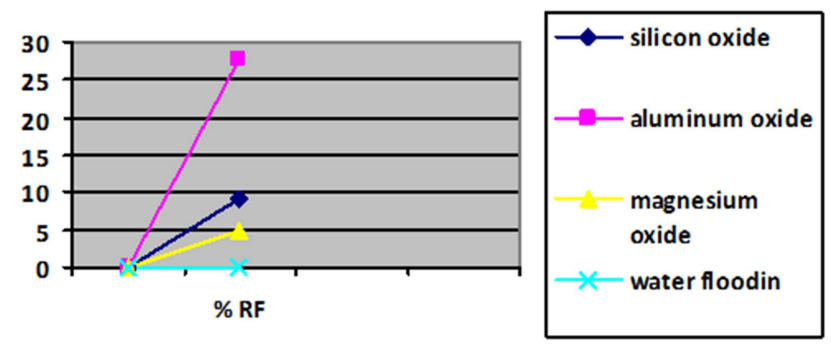

Figure 7. Recovery factor for some metallic oxide nanoparticles at $0.2 \mathrm{wt} \%$.

\section{Discussion}

From the result we can see that aluminium oxide nanoparticles have the highest recovery, followed by silicon oxide with magnesium oxide having the lowest recovery. Analysis of the particles and the observations noticed will give us more insight on their different behaviours.

From figure 7, we can clearly see that aluminum oxide has a higher RF followed by silicon and lastly magnesium oxide.
The recovery factor is subject to the recovery from secondary recovery which is the benchmark for ascertaining the additional recovery by $0.2 \mathrm{wt} \%$ of the following nanoparticles.

During the analysis it was noticed that aluminum oxide nanoparticles reduced the adhesive force between the crude oil and solids. That is an indication that it reduces the wettability of oil in an oil wet rock, making it more water wet. Furthermore, it tremendously reduced the oil-water interfacial tension more than any other nanoparticle used in the analysis as was seen in the ease of oil separation from water during the efflux period.

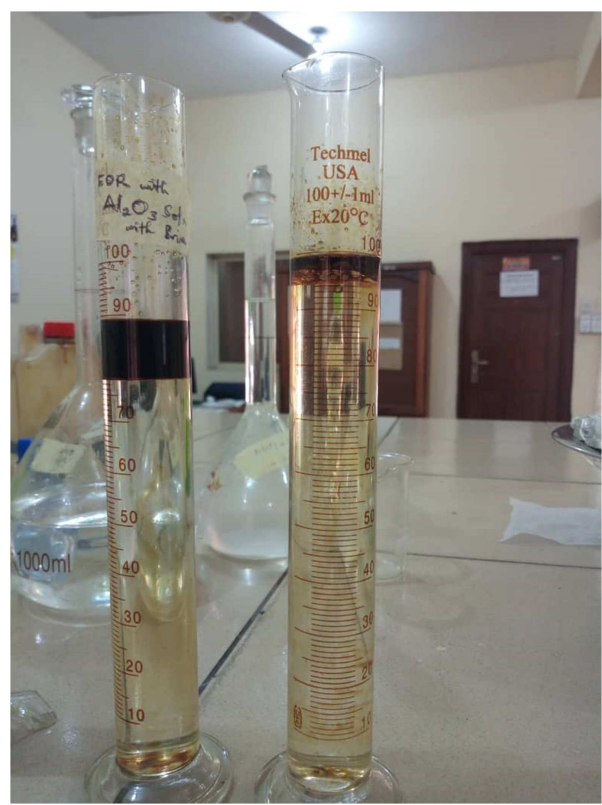

Figure 8. Oil recovered (efflux) from aluminum oxide nanoparticle.

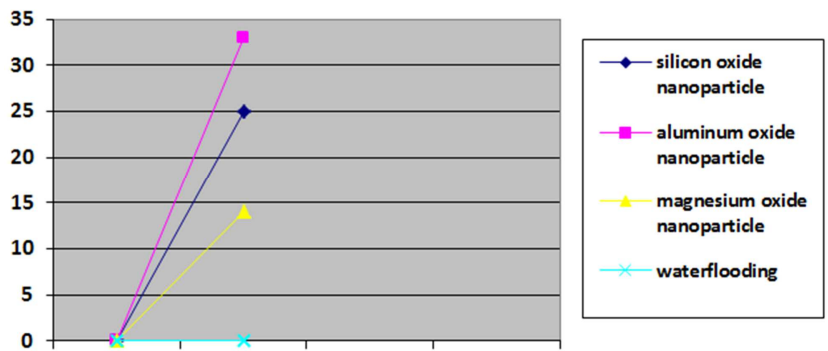

Figure 9. Recovery factor for 0.4 wt\% nanoparticle.

From figure 9, it is seen that there is a slight increase in the recovery factor by aluminum oxide nanoparticle from the 
previous $0.2 \mathrm{wt} \%$. Silicon and magnesium oxide nanoparticles appreciated greatly in their RF as concentration increases therefore, silicon and magnesium nanoparticles performs well at relatively high concentrations.

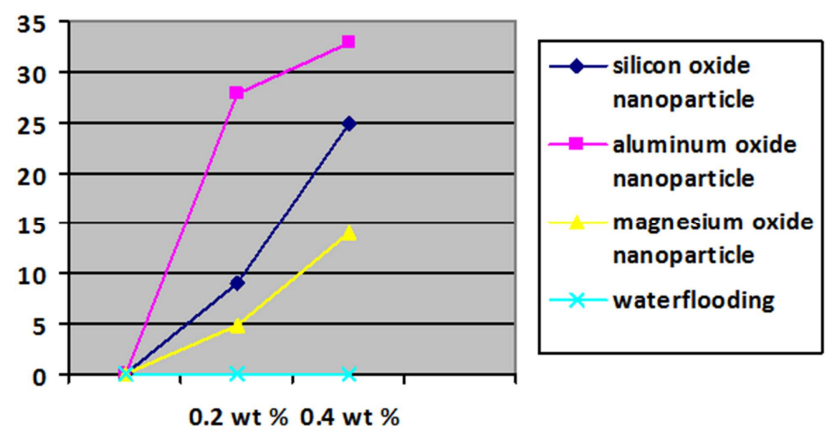

Figure 10. Comparism of 0.2 and $0.4 \mathrm{wt} \%$ recovery factor for some metallic oxide nanoparticles.

\section{Conclusion and Recommendation}

From table 5 we see that aluminum oxide nanoparticle has the highest recovery compared to silicon and magnesium oxide nanoparticle, although as the concentration increases, its recovery factor increases at a lower rate compared to silicon and magnesium oxide nanoparticles (see figure 10). So at high concentration, aluminum oxide nanoparticles may not have a linear recovery factor with lower concentration, it however has a relatively high permeability alteration. It reduces permeability more than silicon and magnesium oxide nanoparticles but recovers more than them. So aluminum oxide nanoparticle is best used at lower concentrations to achieve higher recovery with little alteration to the permeability. Furthermore, it has a shorter water breakthrough time ( 8 minutes) compared to the rest, which implies that it is cost effective and fast.

From figures 10 and 9 silicon oxide nanoparticles perform better at higher concentrations than the rest experimented. It had a breakthrough time of 10 minutes, very effective in wettability alteration and also cost effective.

Magnesium oxide nanoparticle is the least preferred, although it has an increased recover factor at higher concentration (see figures 10 and 9), it has a lower permeability alteration, however it agglomerates faster at lower flow rates and it is not as cost effective like aluminum and silicon oxide nanoparticles.

Aluminum oxide nanoparticle is the best compared to the other metallic oxide nanoparticles experimented on. It has the highest recovery factor, displacement efficiency, and interfacial tension reduction etc. but also alters permeability greatly at high concentrations. It is recommended to be used as;

a) Demulsifier

b) EOR agent

Whenever high concentration is needed, it is preferable to go for silicon oxide nanoparticle. It can be used together with aluminum oxide, with silicon having the higher concentration in the solution. Nanoparticle EOR is cost effective and environmentally friendly but the concentration when not properly checked or controlled will hamper permeability.

I will continue with the research soonest to test more nanoparticles. I hope to consider more concentration values like $0.1 \mathrm{wt} \%, 0.3 \mathrm{wt} \%, 0.5 \mathrm{wt} \%$ and $1 \mathrm{wt} \%$ to have a proper view of the actual sequence of metallic oxide nanoparticles on permeability alteration and their overall effect as EOR agents.

\section{References}

[1] Alexander Sebastian Hogeweg, Rafael E. Hincapie, Hendrik Foedisch and Leonhard Ganzer, 2018. Evaluation of Aluminium Oxide and Titanium Dioxide Nanoparticles for EOR Applications EAGE Conference and Exhibition 1-2 Copenhagen, Society of Petroleum Engineers.

[2] Bayat A, E., Junin, R, Shamshirband, S. 2015. Transport and Retention of Engineered Aluminium Oxide, Titanium Oxide and Silicon Oxide Nanoparticles Through Various Sedimentary Rocks Scientific Reports $\mathrm{p} 5$.

[3] Chen, H., Ding, Y., and Tan, C, 2007. Rheological Behaviour of Nanofluids New Journal of Physics 10.

[4] D. Y. Patil Vidyapeeth, Beuy Joob, Virus Wiwanitkit, 2017. Nanotechnology for Health: A New Useful Technology for Medicine p5.

[5] Elkady Mohammed, 2016. Application of Nanotechnology in EOR, Polymer-Nano Flooding the Nearest Future of EOR. Annual Technical Conference and Exhibition 1-8 Dubia, UAE Society of Petroleum Engineers.

[6] Franck, 2004. Understanding Rheology of Structured Fluids Texas Book of TA Instruments.

[7] Hashemi, N, \& Pereira -Almao, 2012. Transport Behavior of Multimetallic Ultradispersed Nanoparticles in an Oil-Sand-Packed Bed Column at a High Temperature and Pressure Energy Fuels p1645-1655.

[8] Jiang Yang, Sixue Ji, Ran Li, Wenlong Qin and Yongjun Lu, 2015. Advances of Nanotechnologies in Oil and Gas Indutries New York SPE.

[9] Luky Hendraningrat, Li Shidong, Suwamo and Ole Torsaeter, 2012. A Glass Micromodel Experimental Study of Hydrophilic Nanoparticles Retention for EOR Project SPE Russian Oil and Gas Exploration and Production Technical Confrence and Exhibition 1 Moscow, Russia SPE 159161.

[10] Mohammed Haroun, Saeed Al Hassan, Arsalan Ansari, Nabeela Al Kindy, Nada Abou Sayed, Basma Ali, Hemanta Sarma, 2012. Smart Nano-EOR Process for Abu Dhabi Carbonate Reservoirs Abu Dhabi International Petroleum Exhibition \& Conference 1-6 Abu Dhabi Society of Petroleum Engineers.

[11] Muller, G. 1981 Thermal Stability of Polyacrylamide Solutions: Effect of Residual Impurities in the Molecular-Weight-Degradation upon Heating Polymer Bulletin p39-45.

[12] N. A. Ogolo, O. A. Olafuyi, M. O. Onyekonwu, 2012. Enhanced Oil Recovery using Nanoparticles SPE Saudi Arabia Section Technical Symposium and Exhibition1-5 Al-Khobar, Saudi Arabia Society of Petroleum Engineers. 
[13] Nwidee, L. N, 2017. Nanoparticles for Enhanced Oil Recovery Process West Australia, Curtin University.

[14] S. Thomas, 2008. Nanotechnology in EOR SPE journal Hague Oil and Gas Science and Technology p5-6.
[15] Sarmad Al Anssari, Nwidee, Lezorgia, Mohammed Ali, 2017. Retention of Silica Nanoparticle in Limesone Porous Media SPE/IATMI Asia Pacific Oil and Gas Conference and Exhibition 1-5 Jakarta, Indonesia. Society of Petroleum Engineers. 